\title{
Distribution of cysts of Strongyluris sp. (Nematoda) in the pallial system of Achatina fulica Bowdich, 1822 from Vila Dois Rios and Vila do Abraão, Ilha Grande, Angra dos Reis, Rio de Janeiro
}

\author{
J. L. Oliveira ${ }^{*}$ and S. B. Santos ${ }^{a}$
}

aLaboratório de Malacologia Límnica e Terrestre, Departamento de Zoologia, Instituto de Biologia Roberto Alcantara Gomes, Universidade do Estado do Rio de Janeiro - UERJ, Rua São Francisco Xavier, 524, Maracanã, CEP 20550-019, Rio de Janeiro, RJ, Brasil

*e-mail: jaquelopes28@yahoo.com.br

Received: December 13, 2016 - Accepted: July 7, 2017 - Distributed: February 28, 2019

(With 6 figures)

\begin{abstract}
This work aimed to assessing Strongyluris sp. cysts distribution pattern in the several inner organs from pallial system of Achatina fulica Bowdich, 1822. Also we verified if there is a relationship between the mollusk size and the number of specimens from parasites collected from two touristic villages in Ilha Grande (Angra dos Reis, Rio de Janeiro state): Vila Dois Rios (VDR) and Vila do Abraão (ABR). The samples were obtained through a field work conducted bimonthly during 2007, 2008, 2010, and 2011, at both locations. Height and width were measured from shells collected, and the all specimens were classified in different classes: class $1-<4.0 \mathrm{~cm}$, class $2-4.1-9.0 \mathrm{~cm}$ and class $3-<9.0 \mathrm{~cm}$. After the specimens were dissected in order to find and count the number cysts in the pallial system. In specimens from both locations, the pulmonary and secondary veins showed a high number of cysts. No significance difference was found both in the abundance of cysts among the specimens in ABR $(\mathrm{p}=0.138)$ and VDR $(\mathrm{p}=0.181)$. Achatina fulica showed different intensities of cyst infection based on the size classes: the class-3 specimens, at both locations, showed the greatest cyst average (ABR Anova $\mathrm{F}=3.8 ; \mathrm{p}=0.02)$; (VDR $\mathrm{T}$ of Student $\mathrm{T}=-2.04 ; \mathrm{p}=0.04)$. The results suggested that the highest number of cysts in the vascularized area in pallial system of A. fulica was a consequence of a greater hemolymph circulation in that area, delivering more nutrients for larvae development. We think that bigger individuals host a higher number of cysts, as they usually present a larger biomass and a larger area of the pallial system, allowing an efficient parasite colonization. Other possible explanation could be the long exposure of the molluscs of class 3 to the parasites, which allowed a longer time to the larvae to allocate themselves.
\end{abstract}

Keywords: Atlantic Forest, invasive specie, land snail, parasitism, Nematode.

\section{Distribuição de cistos de Strongyluris sp. (Nematoda) no complexo pallial de Achatina fulica Bowdich, 1822 da Vila Dois Rios e da Vila do Abraão, Ilha Grande, Angra dos Reis, Rio de Janeiro}

\begin{abstract}
Resumo
O objetivo do estudo foi analisar o padrão de distribuição dos cistos de Strongyluris sp. nos diversos órgãos do complexo pallial de Achatina fulica Bowdich, 1822 e verificar se existe relação entre o tamanho do molusco e o número de parasitos em espécimes procedentes de dois vilarejos da Ilha Grande, Vila Dois Rios (VDR) e Vila do Abraão (ABR), município de Angra dos Reis, Rio de Janeiro. As coletas foram realizadas bimestralmente nos anos de 2007, 2008, 2010 e 2011 nas duas localidades. A altura e largura das conchas foram medidas, os espécimes classificados em classe $1-<4,0 \mathrm{~cm}$; classe 2 - 4,1-9,0 cm e classe $3-<9,0 \mathrm{~cm}$ e posteriormente dissecados sob estereomicroscópio para a busca e contagem dos cistos no complexo pallial. Em ambas localidades, VDR e ABR, as veias pulmonares e secundárias apresentaram predominância de alocação dos cistos. Não foi encontrada diferença na abundância de cistos entre os espécimes de ABR $(\mathrm{p}=0,138)$ e VDR $(\mathrm{p}=0,181)$. Achatina fulica apresentou intensidades diferentes de infecção de acordo com as classes de tamanho: os espécimes pertencentes a classe 3, nas duas localidades, apresentaram a maior média de cistos visíveis (ABR Anova $\mathrm{F}=3,8 ; \mathrm{p}=0,02$ ); (VDR T de Student $\mathrm{T}=-2,04 ; \mathrm{p}=0,04)$. Os resultados sugerem que o maior número de cistos na região vascularizada de $A$. fulica foi decorrente do maior aporte de hemolinfa nesta área, proporcionando mais nutrientes para o desenvolvimento das larvas. Acreditamos que indivíduos maiores albergam um elevado número de cistos, pois, geralmente, apresentam maior biomassa e maior área da cavidade pallial, possibilitando uma eficiente colonização dos parasitos, outra causa pode ser explicada pelo maior tempo de exposição dos moluscos da classe 3 aos parasitas, que possibilitou um período maior para as larvas se alocarem.
\end{abstract}

Palavras-chave: Mata Atlântica, espécie invasora, molusco terrestre, parasitismo, Nematoda. 


\section{Introduction}

The gastropod Achatina fulica Bowdich, 1822, native from Eastern Africa (Mead, 1961), is considered one of the hundred worst invasive species in the world (IUCN, 2013). One of the hypothesis on the invasion of this mollusk in Brazil establish that $A$. fulica was introduced in the 1980's, in a farming fair promoted by the Brazilian government, as a commercial purpose of replacing the escargot (usually Cornu aspersum Müller, 1774). Then, the country became one of the main producers for the European market (Colley and Fischer, 2009). Currently, the mollusk is present in 24 of the 26 Brazilian states, including islands and environments of protected areas (Thiengo et al., 2008; Faraco, 2011).

Achatina fulica is considered a harmful species to the environment, as it can possibly change the structure of communities and the composition of native populations (CBD, 2011), caused by the direct competition for resources against native mollusk species (Simberloff, 2002), such as Megalobulimus spp. and Thaumastus spp. (Carvalho et al., 2003; Fischer and Colley, 2004; Thiengo et al., 2008; Zenni and Ziller, 2010; Faraco, 2011).

In terms of public health, A. fulica is a potential intermediate host of nematodes of medical importance, such as Angiostrongylus costaricensis Morera and Céspedes, 1971 and Angiostrongylus cantonensis (Chen, 1935), related to the abdominal and meningocerebral angiostrongyliasis (Thiengo et al., 2007; Maldonado Júnior et al., 2010). It can be also a potential both an intermediate and paratenic host of some parasites of wild animals species of Aelurostrongylus Cameron, 1927 (Thiengo et al., 2008; Oliveira et al., 2010) could parasite lung both domestic and wild cats (Ribeiro and Lima, 2001), Rhabditis Dujardin,
1845 , that lodge in the external auditory canal of cattle, causing otitis (Martins Júnior, 1985; Campos et al., 2002; Thiengo, 2009; Barbosa et al., 2016) and Strongyluris Mueller, 1894, which are intestinal parasites mainly found in lizards (Kohn et al., 1973; Vicente et al., 1993; Rocha and Vrcibradic, 2003).

In 2008, Strongyluris larvae were found encysted inside the pallial cavity of specimens of $A$. fulica from Ilha Grande (Thiengo et al., 2008). According to Seehabutr (2005) and Franco-Acuña et al. (2009) several nematodes are parasites of $A$. fulica, but the understanding of their relationship has not yet been clarified. Moreover, as it is a possible paratenic host, facilitated by its soft body, habitat, and generalist habits (Fischer et al., 2010), A. fulica can harbor countless nematodes, which could parasitized the vertebrate fauna when ingested. When spread to new areas, the mollusk also would introduce new parasite species, contributing to the parasitism of the local fauna (Simberloff, 2002; Thiengo et al., 2008).

In order to better understand and clarifie the role of A. fulica as an intermediate host for Strongyluris larvae, this work have as goal aimed to assessing the Strongyluris spp. cysts distribution pattern inside the organs of the pallial system and evaluating if exist a relationship between the mollusk size and the number of parasited specimens in Ilha Grande.

\section{Material and Methods}

The specimens were obtained from Vila Dois Rios (2310'55.73"'S; 44¹1'30.81"W) and Vila do Abraão

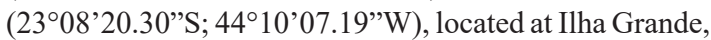
a township of Angra dos Reis, in the south of the Rio de Janeiro state (Figure 1).
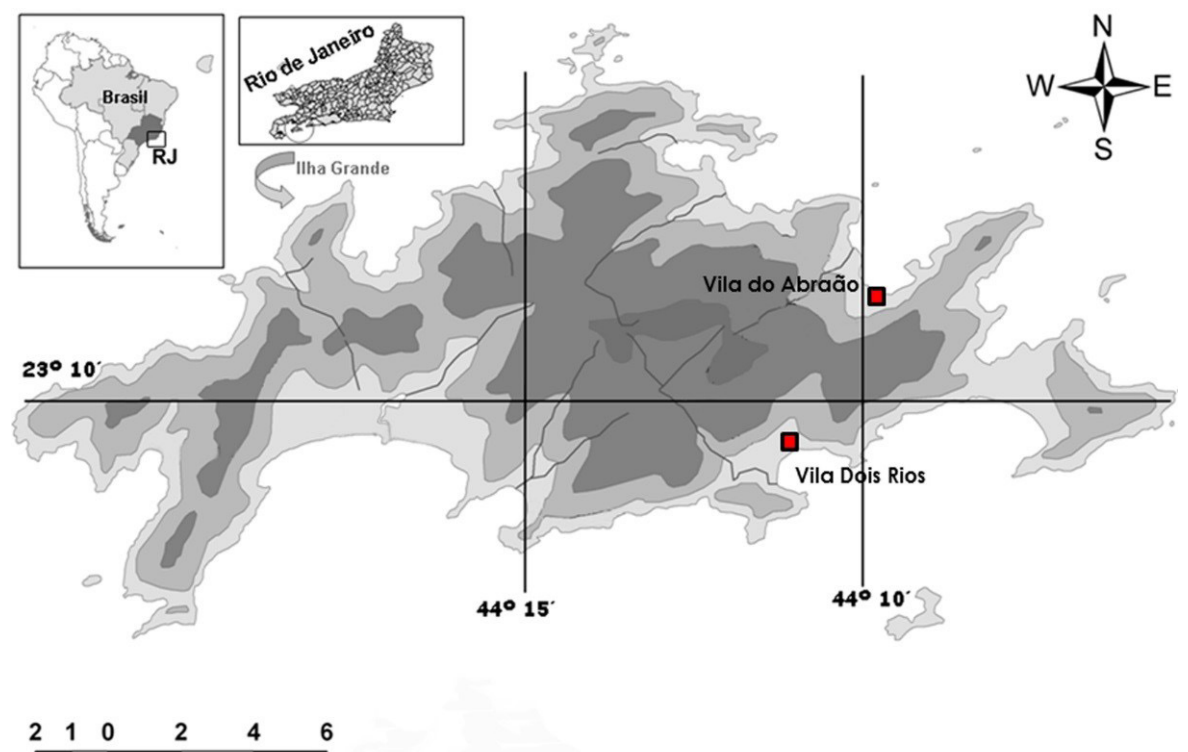

Figure 1. Location map of Ilha Grande in Rio de Janeiro State showing the collecting sites, Vila do Abraão and Vila Dois Rios, pointed out by the red squares. Scale in kilometers. Map: L. E. M. Lacerda. 
The samples were collected bimonthly in 2007, 2008, 2010, and 2011, at both communities. According to the sugestion made by Fischer and Colley (2004) and Albuquerque et al. (2008), the sampling localities were selected based on the mollusk preference in terms of rest and foraging places (hedges, vegetable farming, gardens, garbage, rubble, empty lots, and woods edges).

The specimens collected in 2007 and 2008 were sacrificed by drowning, fixed, and preserved with $70^{\circ} \mathrm{GL}$ alcohol, following the technique described in Thomé (1975). The animals collected in 2010 and 2011 were immediately dissected, after sacrifice (Salgado, 2010).

The height and width of the shells were measured with a $0.05 \mathrm{~mm}$-accuracy Mitutoyo caliper rule, according to Salgado (2010); the specimens were classified as $<4.0 \mathrm{~cm}$ - class $1,4.1-9.0 \mathrm{~cm}$ - class 2 , and $<9.0 \mathrm{~cm}$ - class 3 (Tomiyama and Nakane, 1993; Fischer et al., 2008). In order to retrieve the animal, the shells were cracked with a hammer, wrapped in a newspaper to reduce the impact caused by the hits and to avoid damaging the pallial system. The dissection was conducted by inserting fine point scissors, from the mantle edge, at the pneumostome level, initially cutting near the anus and then along the rectum, exposing the pallial cavity roof, folded to the left. This animal was throughtly examined with naked eye and a Leica MZ6 stereomicroscope in order to find and count the cysts in different organs.

Nematode identification was based on morphology characters according described in Bain (1970), Anderson (2000), Franco-Acuña et al. (2009) and Oliveira et al. (2010).

Non-parametric Kruskal-Wallis test (H test) was used to analyze the cyst distribution pattern in the soft parts of $A$. fulica. The comparison between the size classes and the number of cysts was evaluated by parametric Student $t$ test and ANOVA. After that, we conducted the a posteriori Tukey test to compare the average pairs after the variance analysis.

\section{Results}

We analyzed 851 specimens, from them 544 (64\%) were from Vila do Abraão (ABR) and 307 (36\%) from Vila Dois Rios (VDR), with heights ranging from 1.8 to $12.7 \mathrm{~cm}$ in ABR, and 1.4 to $11.7 \mathrm{~cm}$ in VDR. We found 141 (16.6\%) specimens parasitized with Strongyluris spp. cysts, totalizing 1,898 cysts. In VDR, 45 (32\%) specimens were parasitized, totalizing 629 (33\%) cysts.In ABR, we found 96 (68\%) parasitized specimens, in a total of $1,269(67 \%)$ cysts.

We observed a predominance of the presence of cysts in the pulmonary veins and in the secondary pulmonary veins (SPV) or in both structures (Figures 2 and 3). In the samples from ABR, 1,070 cysts were found in SPV (84.3\%), 164 cysts in the kidney (13\%), 20 cysts in the pericardial

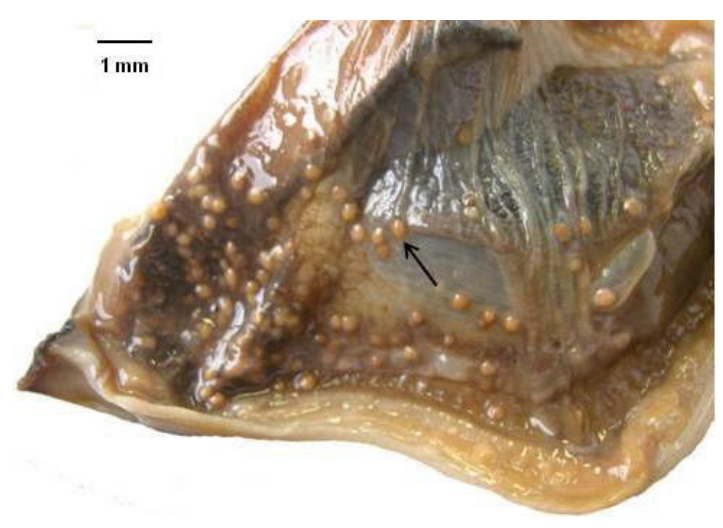

Figure 2. Achatina fulica Bowdich, 1822 pallial cavity of a specimen from Vila Dois Rios, Ilha Grande, Angra dos Reis, RJ, Brazil, with Strongyluris sp. cysts adhering to the secondary veins. The black arrow indicates a cyst $0.8 \mathrm{~mm}$ in diameter. Photo: J. L. Oliveira.

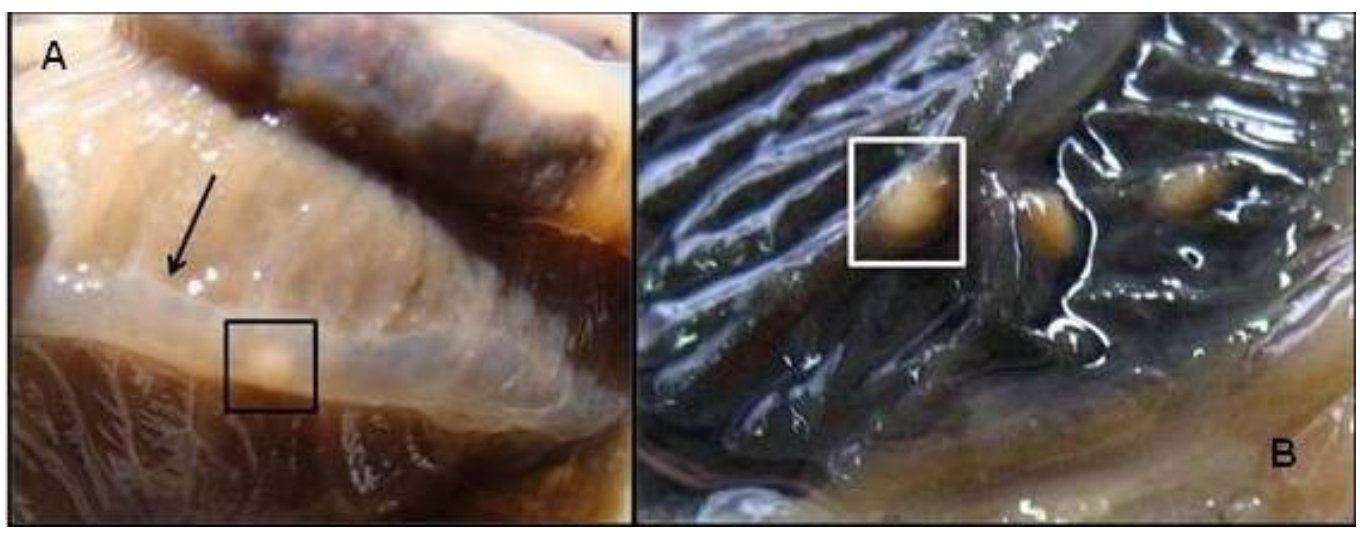

Figure 3. Achatina fulica Bowdich, 1822 from Vila Dois Rios, Ilha Grande, Angra dos Reis, RJ, showing cysts of Strongyluris sp. in the roof of pallial cavity. (A) cyst within the pulmonary vein indicated by the black square; the arrow indicates the large pulmonary vein; (B) cysts inside the secondary veins indicated by the white square. Scale bar $=1 \mathrm{~mm}$. Photos: S. B. Santos. 
sac $(1.5 \%)$, and 15 cysts in the rectum $(1.20 \%)$. In the samples from VDR, 592 cysts were found in SPV (95\%), 14 cysts in the kidney $(2 \%), 7$ cysts in the pericardial sac $(1 \%)$, and 16 cysts in the rectum (2\%) (Table 1$)$.

We did not find significant differences in the abundance of cysts among the organs of specimens in ABR (Kruskal-Wallis, $\mathrm{n}=96, \mathrm{~g} .1 .=3 ; \mathrm{H}=5.515$, $\mathrm{p}=0.138$ ) and VDR (Kruskal-Wallis, $\mathrm{n}=45$, g.l. $=3 ; \mathrm{H}=4.878$; $\mathrm{p}=0.181)$ (Figure 4 and 5).

In order to compare the size classes, 95 infected specimens from ABR were analyzed (one of them presented a broken shell apex and was removed from the analysis, because it was not possible to measure its height), and found that $10 \%$ (10) belonged to class $1,62 \%$ (59) to class 2 , and $28 \%$ (26) to class 3 . In VDR, 44 specimens were assessed, and $59 \%$ of them (26) belonged to class 2 , and $41 \%$ (18) to class 3 . There was not observed parasitized specimens in class 1. Achatina fulica presented different intensities of infection based on the size classes. The results showed that the specimens of class 3 , in both locations, presented a higher average of cysts. The variance analysis performed for the three size classes in ABR revealed that difference: class 1: $2.1 \pm 1.5$; class $2: 8.7 \pm 24.8$; class 3: $28 \pm 49.5$; Anova $\mathrm{F}=3.8 ; \mathrm{p}=0.02$. Tukey post-test revealed a remarkable difference $(\mathrm{p}=0.03)$ only between class 1 and the others. Student's t-test for the VDR data also indicated an significant difference in the average of cysts between the size classes (class 2: $8.15 \pm 16.1$ and class 3: $22.3 \pm 29.7$ ); (Student's t-test= -2.04; $\mathrm{p}=0.04$ ).

According morphological data Franco-Acuña et al. (2009) e Oliveira et al. (2010), the lavae found were identified as L3 larvae of Strongyluris sp. (Figure 6).

Table 1. Organs of Achatina fulica Bowdich, 1822 from Vila do Abraão and Vila Dois Rios, Ilha Grande, Angra dos Reis, Rio de Janeiro, parasitized by Strongyluris sp. by locality, total number of cysts and average of cysts per organ.

\begin{tabular}{|c|c|c|c|c|c|c|c|c|}
\hline & \multicolumn{2}{|c|}{$\begin{array}{c}\text { Secondary pulmonary } \\
\text { veins (SPV) }\end{array}$} & \multicolumn{2}{|c|}{ Kidney } & \multicolumn{2}{|c|}{ Pericardial sac } & \multicolumn{2}{|c|}{ Rectum } \\
\hline & ABR & VDR & ABR & VDR & ABR & VDR & ABR & VDR \\
\hline $\begin{array}{l}\text { Total of parasitized } \\
\text { organs per locality }\end{array}$ & 90 & 45 & 19 & 7 & 8 & 3 & 7 & 4 \\
\hline Total cysts per organ & 1,070 & 592 & 164 & 14 & 20 & 7 & 15 & 16 \\
\hline Average $\pm \mathrm{SD}$ & $11.8 \pm 30.1$ & $13.1 \pm 22.1$ & $8.6 \pm 27.3$ & $2 \pm 1.9$ & $2.5 \pm 1.6$ & $2.3 \pm 1.5$ & $2.1 \pm 2$ & $4 \pm 2.9$ \\
\hline
\end{tabular}

ABR: Vila do Abraão; VDR: Vila Dois Rios.

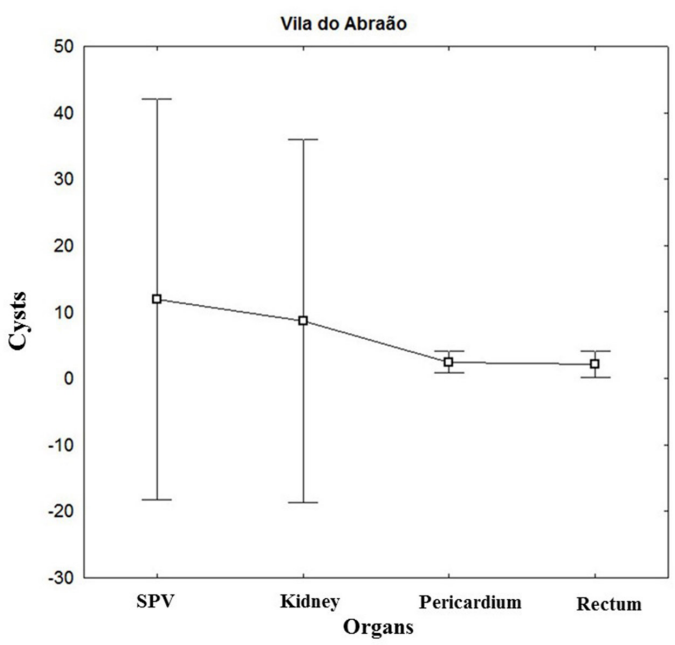

Figure 4. Number of cysts of Strongyluris sp., expressed as mean \pm standard deviation, in the analyzed organs from Achatina fulica Bowdich, 1822 collected in Vila do Abraão, Ilha Grande, Angra dos Reis, Rio de Janeiro, from 2007 to 2011. SPV - Secondary pulmonary veins.

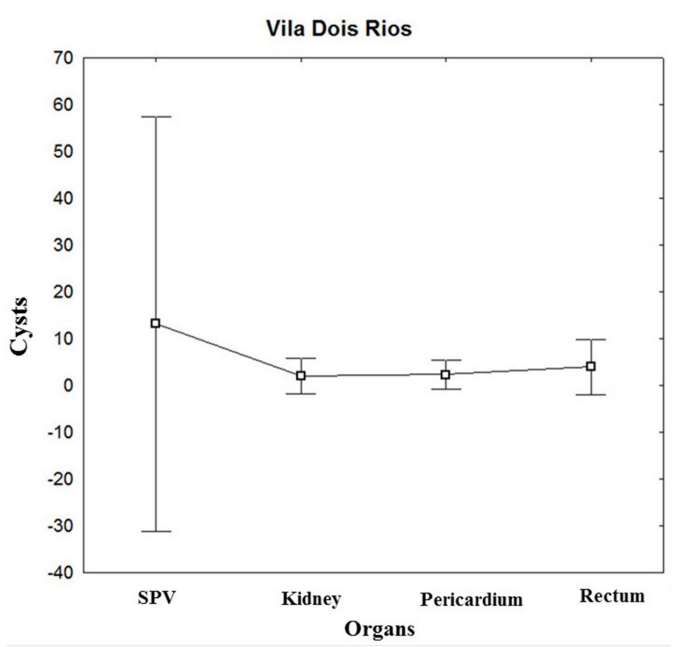

Figure 5. Number of cysts of Strongyluris sp., expressed as mean \pm standard deviation, in the analyzed organs from Achatina fulica Bowdich, 1822 collected in Vila Dois Rios, Ilha Grande, Angra dos Reis, Rio de Janeiro, from 2007 to 2011. SPV - Secondary pulmonary veins. 


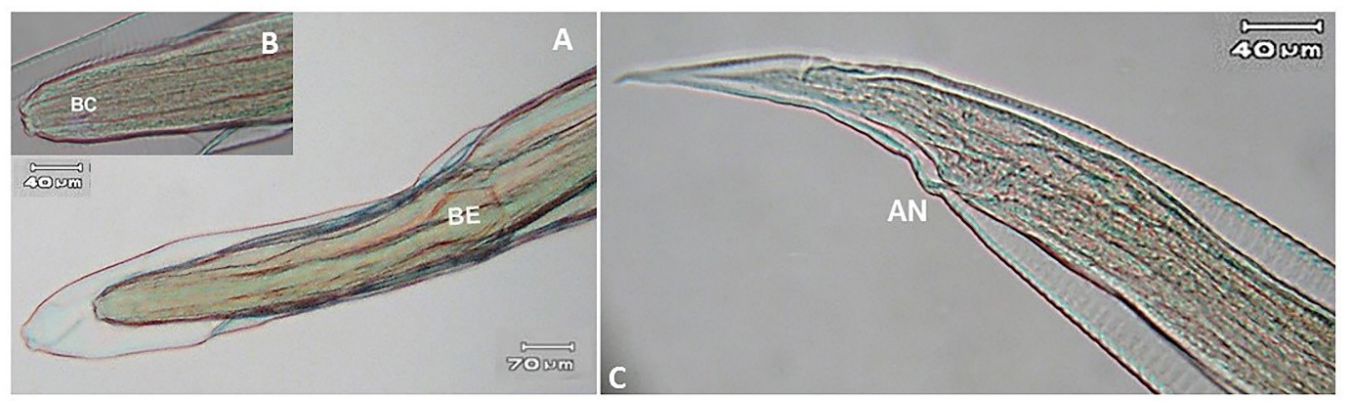

Figure 6. Strongyluris sp. from Achatina fulica Bowdich, 1822 collected at Vila Dois Rios, Ilha Grande, Angra dos Reis, Rio de Janeiro. (A) anterior end demonstrating the bulbiform esophagus (BE); (B) buccal capsule (BC); (C) posterior end with the anus (AN) and dorsoventrally curved tail. Photo: A.P.M. Oliveira.

\section{Discussion}

Strongyluris Mueller, 1894 is a intestinal parasite belongs to the family Heterakidae, mostly found in lizards (Kohn et al., 1973; Vicente et al., 1993; Anderson, 2000) and rarely in anuran amphibians (Bursey et al., 2003). Strongyluris spp larvae were found in terrestrial molluscs in Brasil, like Bradybaena similaris (Férussac, 1821), Bulimulus tenuissimus (d'Orbigny, 1835), Belocaulus angustipes (Heyneman, 1885), Megalobulimus sp., Phyllocaulis variegatus (Semper, 1885), Sarasinula marginata (Semper, 1885) and Subulina octona (Bruguière, 1792). for the first time by Thiengo (1995).

Anderson (2000) described the life cycle of the species of Strongyluris as monoxenic; we consider therefore the eggs with infective larvae are being offered on the soil and leaf litter by the definitive host for Achatina fulica, which ingests them while searching for food. However, Barreto-Lima and Anjos (2014) indicated S. oscari as a heteroxenic parasite, using arthropods as intermediate hosts. Then, we can consider that the infection of Achatina fulica by Strongyluris spp. larvae could be explained by the role of the snail as an intermediate host, as observed by Valente et al. (2016). This hypothesis can be accepted, as Fischer et al. (2010) mentions that the habitat and habits of A. fulica facilitate the parasitism in this species.

Its is suggested that the greatest number of cysts in the vascularized area of A. fulica was a consequence of a great hemolymph circulation and, consequently, nutrients availability in that area, which delivered more requirements for larval development, as proposed by Bain (1970), based on experiments. The author infected cockroaches Blatella germanica species (Linnaeus, 1775) and mosquitoes Culex sp. with larvae of S. brevicaudata Mueller, 1849. As a result he noted that third-stage larvae were found in the general body cavity, region rich in hemolymph in the two species. In the mosquitoes, besides the presence of larvae in the body cavity, some were located in the chest within thin-walled cysts filled with fat globules. The search for nutrients for larva development by parasites in the intra-mollusk phase can be observed in an essay with Bradybaena similaris (Férrussac, 1821) infected by a larval trematode, conducted by Pinheiro and Amato
(1994). The authors noticed an outstanding decrease in the hemolymph glucose content of the parasitized mollusk after a few days of infection.

Given that the mantle region is one of the main storage sites of glycogen in terrestrial gastropods, the hemolymph that supplies this area is rich in glucose (Pinheiro, 2007). The mantle region is a strategic site to warrant larval development by providing the types and amount of nutrients required.

Hemolymph in A. fulica also features high cholesterol levels, a result of the metabolism of lipids in these animals (Lustrino et al., 2010). This factor can also explain the preference of larvae allocation in the mantle organs, as for filling the cysts and folding the larvae, are necessary amounts of fat that possibly were easily acquired from hemolymph flowing in this region.

We believe that larger individuals house a higher number of cysts, as they usually show a larger area in the pallial cavity roof which in turn allows an efficient parasite colonization, or because the longer exposure of the molluscs from class 3 to the parasites, which allowed a longer time to the larvae to allocate themselves (Franco-Acuña et al., 2009). The non-registration of cysts on individuals of class 1 , may have been due to not verifying the tissues through histological sections, to the search for microscopic sizes cysts.

Another hypothesis can also be explained by the probable relation between the food preference and the ontogenetic development of the species (Fischer et al., 2008). Fischer et al. (2008) observed in a study of the African snail diet that individuals who reach larger sizes (adults) consumed specially plant litter. With this behavior in mind, we can perceive a possible infection route of that species by the Strongyluris spp., as the nematode eggs are certainly being offered on the soil and the plant litter by the definitive host, in order to be freely ingested by A. fulica adult specimens. Other possible infection routes could take place through geophagia, coprophagia, and necrophagy, considering that these sources are contaminated. These eating habits are also common in larger specimens (Mead, 1961; Albuquerque et al., 2008). 
The immunological stress caused by the senescence can also increase animals vulnerability to parasites (Mead, 1961). The gradual reduction in the organism physiological functions of old mollusks (class 3) probably facilitated the access and the establishment of parasites in the studied specimens.

This work stresses the need for more studies about the relation of the helminth fauna with the invasive mollusks and the potential role of the African snail as a intermediate host for parasites that can reach the wild fauna in Brazil (Thiengo and Fernandez, 2010). These data contribute to the increase of information on the role of $A$. fulica in life cycle of parasites of medical and veterinary significance (Faraco, 2011). Besides increase of knowledge the present study show and reinforce others as Franco-Acuña et al. (2009) and Maldonado Júnior et al. (2010), that, in spite of the great importance of $A$. fulica acts as intermediate host to $A$. cantonensis, as proven by other authors, the risk that this snails bring to public health and environment is greater than usually we can imagine. There are some kind of parasites that are found in A. fulica that are not known and we do not even know what kind of damages they can cause to human or domestic and wild animals. By this reason, the present study, supported by previous ones, focused the importance to analyze the parasitic fauna in A. fulica, as well as the possible relationship between the parasite and the snail and vertebrate host.

\section{Acknowledgements}

We would like to thanks Dr. Ana Paula Oliveira (Fiocruz-RJ), who kindly provide us with a photograph of Strongyluris larvae and Dr. Silvana Carvalho Thiengo (Fiocruz-RJ) who certificate the parasite identification; JLO thanks Fundação Carlos Chagas Filho de Amparo a Pesquisa do Estado do Rio de Janeiro (FAPERJ) for scholarships (2010-2012) IC/Faperj E-26/102.319/2010; SBS thanks FAPERJ for financial support E-26/110.430/2007, APQ1 E-26/110.402/2010, E-26/111.573/2013; CEADS/UERJ for field research facilities; IBAMA for Sisbio license 10812-1 and INEA for license 18/2007.

\section{References}

ALBUQUERQUE, F.S., PESO-AGUIAR, M.C. and ASSUNÇÃOALBUQUERQUE, M.J.T., 2008. Ecologia do caracol exótico Achatina fulica (Gastropoda:Pulmonata) no nordeste do Brasil. Brazilian Journal of Biology $=$ Revista Brasileira de Biologia, vol. 68 , no. 4 , pp. 837-842. http://dx.doi.org/10.1590/S151969842008000400020 .

ANDERSON, R.C., 2000. Nematodes parasites of vertebrates: their development and transmission. 2nd ed. Wallingford: CABI Publishing, 270 p. http://dx.doi.org/10.1079/9780851994215.0000.

BAIN, O., 1970. Cycle evolutif de 1'Heterakidae Strongyluris brevicaudata (Nematoda): mise em évidence de deux mues dans l'oeuf. Annals of Parasitology, vol. 45, no. 5, pp. 637-653. PMid:5533890.
BARBOSA, J.D., SILVA, J.B., LIMA, H.S., ARAÚJO, L.H.V., SANTOS, L.L., REIS, A.S.B., SALVARANI, F.M. and BRITO, M.F., 2016. Detecção e tratamento de otite por Rhabditis blumi em bovinos da região Norte do Brasil. Pesquisa Veterinária Brasileira, vol. 36, no. 7, pp. 605-610. http://dx.doi.org/10.1590/ S0100-736X2016000700008.

BARRETO-LIMA, A.F. and ANJOS, L.A., 2014. Occurrence of Strongyluris oscari (Nematoda; Heterakidae) in Enyalius bilineatus (Squamata: Leiosaurinae) from the Brazilian Atlantic Forest. Herpetology Notes, vol. 7, pp. 455-456.

BURSEY, C.R., GOLDBERG, S.R. and TELFORD JUNIOR, S.R., 2003. Strongyluris panamaensis $\mathrm{n}$. sp. (Nematoda: Heterakidae) and other helminths from the lizard, Anolis biporcatus (Sauria: Polychrotidae), from Panama. The Journal of Parasitology, vol. 89, no. 1, pp. 118-123. http://dx.doi.org/10.1645/00223395(2003)089[0118:SPNSNH]2.0.CO;2. PMid:12659313.

CAMPOS, D.M.B., ARAÚJO, J.L.B., VIEIRA, M.C.M., DAMASCENO, F. and BARBOSA, A.P., 2002. Um caso de parasitismo por Rhabditis sp. em criança natural de Goiânia, Goiás, Brasil. Revista da Sociedade Brasileira de Medicina Tropical, vol. 35, no. 5, pp. 519-522. http://dx.doi.org/10.1590/ S0037-86822002000500016. PMid:12621674.

CARVALHO, O.S., TELES, H.M.S., MOTA, E.M., MENDONÇA, C.L.G.F. and LENZI, H.L., 2003. (Mollusca: Gastropoda) as intermediate host of the Angiostrongylus costaricensis Morera \& Céspedes 1971. Revista da Sociedade Brasileira de Medicina Tropical, vol. 36, no. 6, pp. 743-745. http://dx.doi.org/10.1590/ S0037-86822003000600017. PMid:15049117.

COLLEY, E. and FISCHER, M.L., 2009. Avaliação dos problemas enfrentados no manejo do caramujo gigante africano Achatina fulica (Gastropoda: Pulmonata) no Brasil. Zoologia, vol. 26, no. 4, pp. 674-683. http://dx.doi.org/10.1590/S1984-46702009000400012.

CONVENTION ON BIOLOGICAL DIVERSITY - CBD, 2011 [viewed 7 June 2011]. What are invasive alien species? [online]. Montreal: CBD. Available from: http://www.cbd.int/invasive/ WhatareIAS.shtml

FARACO, F.A., 2011. Controle de Achatina fulica Bowdich, 1822 em Unidades de Conservação: um estudo de caso em Poço das Antas, Rio de Janeiro. In: M.A. FERNANDEZ, S.B. SANTOS, A.D., PIMENTA and S.C. THIENGO, eds. Tópicos em malacologia: ecos do XIX Encontro Brasileiro de Malacologia. Rio de Janeiro: Sociedade Brasileira de Malacologia, pp. 362-372.

FISCHER, M.L. and COLLEY, E., 2004. Diagnóstico da ocorrência do caramujo gigante africano Achatina fulica Bowdich, 1822 na APA de Guaraqueçaba, Paraná, Brasil. Revista de Estudos de Biologia, vol. 26, no. 54, pp. 43-50.

FISCHER, M.L., COLLEY, E., AMADIGI, S.N.I. and SIMIÃO, M.S., 2010. Ecologia de Achatina fulica. In: M.L. FISCHER and L.C.M. COSTA, eds. O caracol gigante africano Achatina fulica no Brasil. Curitiba: Editora Champagnat, pp. 101-140.

FISCHER, M.L., COSTA, L.C.M. and NERING, I.S., 2008. Utilização de recursos alimentares presentes no ambiente antrópico pelo caramujo gigante africano Achatina fulica Bowdich, 1822: subsídios para o manejo. Bioikos, vol. 22, no. 2, pp. 91-100.

FRANCO-ACUÑA, D.O., PINHEIRO, J., TORRES, E.J.L., LANFREDI, R.M. and BRANDOLINI, S.V.P.B., 2009. Nematodes cysts and larvae found in Achatina fulica Bowdich, 1822. Journal of Invertebrate Pathology, vol. 100, no. 2, pp. 106-110. http:// dx.doi.org/10.1016/j.jip.2008.11.008. PMid:19061895. 
INTERNATIONAL UNION FOR CONSERVATION OF NATURE - IUCN , 2013 [viewed 18 March 2014]. Invasive Species Specialist Group (ISSG) [online]. Cambridge. Available from: http://www.issg.org/worst100 species.htm

KOHN, A., PINTO, R.M. and FERNANDES, B.M.M., 1973. Contribuição ao conhecimento de Strongyluris oscari Travassos, 1923 (Nematoda, Subuluroidea). Memórias do Instituto Oswaldo Cruz, vol. 7, no. 3, pp. 219-225. http://dx.doi.org/10.1590/S007402761973000200002 .

LUSTRINO, D., TUNHOLI-ALVES, V.M., TUNHOLI, V.M., MARASSI, M.P. and PINHEIRO, J., 2010. Lipids analysis in hemolymph of African giant Achatina fulica (Bowdich, 1822) exposed to different photoperiods. Brazilian Journal of Biology = Revista Brasileira de Biologia, vol. 70, no. 1, pp. 129-134. http:// dx.doi.org/10.1590/S1519-69842010000100018. PMid:20231969.

MALDONADO JÚNIOR, A., SIMÕES, R.O., OLIVEIRA, A.P.M., MOTTA, E.M., FERNANDEZ, M.A., PEREIRA, Z.M., MONTEIRO, S.S., TORRES, E.J.L. and THIENGO, S.C., 2010. First report of Angiostrongylus cantonensis (Nematoda: Metastrongylidae) in Achatina fulica (Mollusca: Gastropoda) from Southeast and South Brazil. Memorias do Instituto Oswaldo Cruz, vol. 105, no. 7, pp. 938-941. http://dx.doi.org/10.1590/ S0074-02762010000700019. PMid:21120369.

MARTINS JÚNIOR, W., 1985. Rhabditis (Rhabditis) freitasi sp. N. e Rhabditis (Rhabditis) costais sp. N. (Nematoda-Rhabditidae) isolados de otite bovina. Memórias do Instituto Oswaldo Cruz, vol. 80 , no. 1, pp. 11-16. http://dx.doi.org/10.1590/S007402761985000100002. PMid:4088041.

MEAD, A.R., 1961. The giant African snail: a problem in economic malacology. Chicago: University of Chicago Press, 257 p.

OLIVEIRA, A.P.M., TORRES, E.J.L., MALDONADO, A., ARAÚJO, J.L.B., FERNANDEZ, M.A. and THIENGO, S.C., 2010. Achatina fulica como hospedeiro intermediário de nematódeos de interesse médico-veterinário em Goiás, Brasil. Revista de Patologia Tropical, vol. 39, no. 3, pp. 199-210. http://dx.doi. org/10.5216/rpt.v39i3.12211.

PINHEIRO, J. and AMATO, S.B., 1994. Eurytrema coelomaticum (Digenea, Dicrocoeliidae): the effect of infection on carbohydrate contents of its intermediate snail host, Bradybaena similaris (Gastropoda, Xanthonychidae). Memórias do Instituto Oswaldo Cruz, vol. 89, no. 3, pp. 407-410. http://dx.doi.org/10.1590/ S0074-02761994000300020.

PINHEIRO, J., 2007. Alterações fisiológicas nas interações entre larvas de trematódeos e seu primeiro hospedeiro intermediário moluscos. In: S.B. SANTOS, A.D. PIMENTA, S.C. THIENGO, M.A. FERNANDEZ and R.S. ABSALÃO, eds. Tópicos em malacologia: ecos do XVIII Encontro Brasileiro de Malacologia. Rio de Janeiro: Sociedade Brasileira de Malacologia.

RIBEIRO, V.M. and LIMA, W.S., 2001. Larval production of cats infected and re-infected with Aelurostrongylus abstrusus (Nematoda: Protostrongylidae). Revue de Medecine Veterinaire, vol. 11 , no. 152 , pp. 815-820.

ROCHA, C.F.D. and VRCIBRADIC, D., 2003. Nematode assemblages of some insular and continental lizard hosts of the genus Mabuya Fitzinger (Reptilia, Scincidae) along the eastern Brazilian coast. Revista Brasileira de Zoologia, vol. 20, no. 4, pp. 755-759. http://dx.doi.org/10.1590/S0101-81752003000400031.

SALGADO, N.C., 2010. Morfologia e taxonomia: recaracterização de Achatina (Lissachatina) fulica (Mollusca, Gastropoda, Stylommatophora, Achatinidae), In: M.L. FISCHER and L.C.M.
COSTA, eds. O caracol gigante africano Achatina fulica no Brasil. Curitiba: Editora Champagnat, pp. 13-47.

SEEHABUTR, V., 2005. Nematodes in alimentary tracts of Giant African snails (Achatina fulica) in Thailand. Kamphaengsaen Academy Journal, vol. 3, no. 1, pp. 37-41.

SIMBERLOFF, D., 2002 [viewed 26 october 2002]. Impacts of introduced species in the United States [online]. Washington. Available from: http://gcrio.gcrio.org/consequences/vol2no2/ article2.html

THIENGO, S.C. and FERNANDEZ, M.A., 2010. Achatina fulica: um problema de saúde pública? In: M.L. FISCHER and L.C.M. COSTA, eds. O caracol gigante Africano Achatina fulica no Brasil. Curitiba: Editora Champagnat, pp. 189-202.

THIENGO, S.C., 1995. Presence of Strongyluris-like larvae (Nematoda) in some Terrestrial Mollusc in Brazil. Memórias do Instituto Oswaldo Cruz, vol. 90, no. 5, pp. 619-620. http:// dx.doi.org/10.1590/S0074-02761995000500014. PMid:8569476.

THIENGO, S.C., 2009. Infestação de Achatina fulica no Brasil: aspectos relacionados à saúde humana e animal. In: Anais do XXI Encontro Brasileiro de Malacologia, 2009, Rio de Janeiro, Brazil. Rio de Janeiro: Sociedade Brasileira de Malacologia, pp. 81-83.

THIENGO, S.C., FARACO, F.A., SALGADO, N.C., COWIE, R.H. and FERNANDEZ, M.A., 2007. Rapid spread of an invasive snail in South America: the giant African snail, Achatina fulica, in Brasil. Biological Invasions, vol. 9, no. 6, pp. 693-702. http:// dx.doi.org/10.1007/s10530-006-9069-6.

THIENGO, S.C., FERNANDEZ, M.A., TORRES, E.J.L., COELHO, P.M. and LANFREDI, R.M., 2008. First record of a nematode Metastrogyloidea (Aelurostrongylus abstrusus larvae) in Achatina (Lissachatina) fulica (Mollusca, Achatinidae) in Brazil. Journal of Invertebrate Pathology, vol. 98, no. 1, pp. 34-39. http://dx.doi. org/10.1016/j.jip.2007.10.010. PMid:18078952.

THOMÉ, J.W., 1975. Distensão de moluscos terrestres para fixação, com comentários sobre coleta e transporte. Arquivos do Museu Nacional, vol. 55, pp. 153-154.

TOMIYAMA, K. and NAKANE, M., 1993. Dispersal patterns of the giant african snail Achatina fulica (Férussac) (Stylommatophora: Achatinidae), equipped with a radio-transmitter. The Journal of Molluscan Studies, vol. 59, no. 3, pp. 315-322. http://dx.doi. org/10.1093/mollus/59.3.315.

VALENTE, R., DIAZ, J.I., LORENTI, E., SALOMÓN, O.D. and NAVONE, G.T., 2016. Nematodes from Achatina fulica Bowdich, 1822 (Mollusca: Gastropoda) in Argentina. Helminthologia, vol. 53, no. 1, pp. 109-112. http://dx.doi.org/10.1515/helmin-2015-0071.

VICENTE, J.J., RODRIGUES, H.O., GOMES, D.C. and PINTO, R.M., 1993. Nematóides do Brasil. Parte III: nematóides de répteis. Revista Brasileira de Zoologia, vol. 10, no. 1, pp. 19-168. http:// dx.doi.org/10.1590/S0101-81751993000100003.

ZENNI, R.D. and ZILLER, S.R., 2010. Invasões biológicas: problemas econômicos e ambientais com ênfase em Achatina fulica. In: M.L. FISCHER and L.C.M. COSTA, eds. O caracol Gigante Africano Achatina fulica no Brasil. Curitiba: Champagnat, pp. $175-188$ 